\title{
ANALISIS KECURANGAN AKADEMIK MELALUI RUBRIK PENSKORANPADA KAJIAN MASALAH EKONOMI
}

\author{
David Firna Setiawan \\ Program Studi Pendidikan Ekonomi Universitas PGRI Semarang \\ davidfirnasetiawan@gmail.com
}

\begin{abstract}
Abstrak
Kecurangan akademik seringkali terjadi dalam tes formatif maupun sumatif. Beberapa bentuk kecurangan yang umum terjadi yaitu (1) memberi, mengambil, atau menerima informasi tertentu (2) menggunakan suatu alat yang dilarang, (3) memanfaatkan kelemahan orang, prosedur, maupun proses untuk mendapatkan keuntungan. Artikel ini bertujuan untuk mendiskripsikan metode analisis kecurangan mengerjakan soal yang mengarah pada plagiarisme dalam bentuk kegiatan memberi, mengambil atau menerima informasi tertentu berkaitan dengan jawaban tes formatif maupun tes sumatif. Metode yang digunakan menekankan pada tiga langkah analisis yaitu (1) unjuk kerja (performance), (2) kriteria unjuk kerja (performance criteria), serta (3) rubrik penskoran (scoring rubric). Hasil analisis diharapkan mampu memberikan data kecurangan akademik yang dilakukan oleh siswa.

Kata kunci : Kecurangan Akademik, Rubrik Penskoran, Kajian Masalah Ekonomi.
\end{abstract}

\section{PENDAHULUAN}

Pembelajaran merupakan interaksi antara peserta didik dengan guru, peserta didik lainserta interaksi dengan lingkungan baik secara parsial maupun simultan. Dalam proses interaksi tersebut, seringkali terdapat berbagai masalah. Salah satu permasalahan yang umum terjadi adalah kecurangan dalam mengerjakan soal baik formatif, sumatif maupun ujian nasional.

Bentuk kecurangan merupakan salah satu indikator rendahnya karakter jujur siswa. Apabila dibiarkan, tentu akan memberikan pengaruh negatif terhadap perkembangan sikap siswa. Penelitian yang dilakukan oleh Noris \& Swift (2001) menyebutkan terdapat korelasi yang kuat antara perilaku curang yang dilakukan oleh mahasiswa program studi bisnisdan manajemen pada semua strata dengan perilaku tidak etis yang mereka tampakkan di tempat kerja. Pernyataan tersebut didukung dengan hasil penelitian Davis \&
Ludvigson (1995) serta Nonis \& Swift (1998) yang menunjukkan bahwa seseorang yang melakukan kecurangan di masa lalu cenderung akan mengulanginya bahkan ketika pelaku telah berada pada lingkungan kerja.

Data menunjukkan bahwa perilaku tidak jujur benar-benar terjadi dikalangan siswa baik pada jenjang pendidikan dasar, menengah maupun pendidikan tinggi. Survey Litbang Media Group (Pudjiastuti, 2012) menunjukkan bahwa mayoritas anak didik, baik dibangku sekolah maupun perguruan tinggi melakukan kecurangan akademik dalam bentuk mencontek. Kasus yang pernah di tayangkan pada acara tvOne 10 Juni 2011 bahkan menunjukkan seorang ibu yang dikucilkan dilingkungannya akibat melaporkan adanya kecurangan masal di sekolah anaknya. Hal itu menunjukkan bahwa perilaku jujur bahkan telah mempengaruhi sikap orang tua. 
Hasil penelitian yang dilakukan Pusat Psikologi Terapan Jurusan Psikologi Universitas Pendidikan Indonesia (UPI) terhadap pelaksanaan ujian nasional (UN) tahun 2004 hingga 2013 menunjukkan bahwa kecurangan UN terjadi secara massal lewat aksi mencontek, serta melibatkan peran tim sukses yang terdiri dari guru, kepala sekolah, dan pengawas. Jumlah responden dalam survei UN adalah 597 orang yang berasal dari 68 kota dan 89 kabupaten di 25 provinsi.Responden berasal dari sekolah negeri sebanyak $77 \%$ dan sekolah swasta sebanyak 20\%. Para responden mengikuti UN antara tahun 2004-2013. Dari hasil survei, 75\% responden mengaku pernah menyaksikan kecurangan dalam UN. Jenis kecurangan terbanyak yang diakui adalah mencontek massal lewat pesan singkat (SMS), grup chat, kertas contekan, atau kode bahasa tubuh. Ada pula modus jual beli bocoran soal dan peran dari tim sukses (guru, sekolah, pengawas) atau pihak lain (bimbingan belajar dan joki). Survei yang dilakukan juga menguungkap bahwa sebagian besar responden tidak melakukan apa pun saat melihat aksi kecurangan. Sedangkan sisanya ikut melakukan kecurangan atau sekadar sebagai pengamat. Hasil survei juga menunjukkan rendahnya kesadaran responden untuk lebih kooperatif ditandai dengan rendahnya aktivitas pelaporan kecurangan yaitu sebesar 3\%.

Salah satu faktor yang menjadi sebab terjadinya kecurangan adalah kondisi saat ujian dilaksanakan (Hendicks, 2004). Kondisi tersebut diteruskan dengan lemahnya kompentensi profesional guru dalam melakukan koreksi. Oleh sebab itu, diperlukan sebuah metode yang tepat untuk menganalisis peluang siswa berbuat curang berdasarkan hasil kerjanya terhadap ujian formatif maupun sumatif.

Beberapa bentuk kecurangan yang terjadi dikalangan akademisi termasuk siswa adalah plagiarisme (aktivitas meniru karya orang lain tanpa ijin), serta aktivitas mencontek.

Tujuan penulisan artikel ini adalah untuk mendiskripsikan metode analisis kecurangan mengerjakan soal yang mengarah pada plagiarisme dalam bentuk kegiatan memberi, mengambil atau menerima informasi tertenu berkaitan dengan jawaban tes formatif maupun tes sumatif. Penulisan artikel ini dilator belakangi oleh penelitian yang dilakukan oleh Davy, (2007). Hasil penelitian menunjukkan bahwa terdapat hubungan positif yang signifikan antara motivasi ekstrinsik yang diukur berdasarkan harapan atas pekerjaan dan gaji di masa yang akan datang. Seseorang yang memiliki harapan besar terhadap pekerjaan, prestise dan gaji lebih cenderung berbuat curang. Disisi lain motivasi intrinsik yang diukur dari kesenangan memahami sesuatu dan mendapatkan pengalaman baru dalam belajar menunjukkan hubungan yang sebaliknya terhadap kecenderungan berbuat curang.

Salah satu metode yang akan diuraikan dalam artikel ini adalah identifikasi kecurangan berdasarkan analisis data yang diperoleh pada saat melakukan skoring terhadap hasil kerja siswa. Metode tersebut diharapkan mampu memberikan keterampilan kepada guru untuk mengidentifikasi kecurangan siswa sehingga dapat dilakukan tindakan akademis untuk memberikan efek jera serta mengantisipasi kecurangan tersebut agar tidak terjadi kembali.Karena menurut 
Panadero \& Jonsson (2013) rubrik secara potensial mampu mempengaruhi siswa untuk belajar lebih positif. Kajian materi yang dijadikan objek pembahasan adalah masalah ekonomi.

\section{KAJIAN PUSTAKA}

\section{Kecurangan Akademik}

Kecurangan akademik memiliki definisi yang sangat luas. Salah satu definisi mengenai kecurangan akademik dikemukakan oleh Sagoro (2013) yang mengemukakan bahwa kecurangan akademik adalah perbuatan tidak jujur dan melanggar peraturan yang dilakukan untuk mencapai tujuan tertentu.

Kecurangan akademik atau dalam bahasa inggris disebut sebagai(academic dishonesty) merupakan berbagai bentuk perilaku yang mendatangkankeuntungan bagi siswa secara tidak jujur. Menurut Hendricks (2004) bentuk perilaku tersebut diantaranya, (1) mencontek, plagiarisme,

(3) mencuri, dan memalsukan sesuatu yang berhubungan dengan akademis.Lambert, Hogan dan Barton (2003) mengemukakan bahwa kecurangan akademik merupakan salah satu tindakan yang bertentangan dengan etika.Kecurangan tersebut terjadi apabila siswa melakukan berbagai cara yang tidak baik untuk mencapai tujuan tertentu. Tujuan ini erat kaitannya dengan kompetensi dan seringkali berhubungan dengan nilai atau prestasi akademik. Menurut Hendricks (2004) terdapat beberapa faktor yang mempengaruhi kecurangan akademis. Faktor tersebut diantaranya adalah sebagai berikut.

a. Faktor individual yaitu, usia, jenis kelamin, prestasi akademik, pendidikan orang tua, serta aktivitas ekstrakurikuler. Faktor tersebut merupakan variabel dependen yang berpengaruh baik positif maupun negatif. Siswa dengan usia lebih muda, seringkali melakukan lebih banyak kecurangan daripada yang berusia lebih tua. Berdasarkan teori sosialisasi peran gender, di mana dalam melakukan sosialisasi, wanita lebih taat aturan daripada pria. Teori ini menjadi dasar hipotesis bahwa pria memiliki peluang lebih besar untuk melakukan kecurangan dari pada wanita. Tidak seperti faktor usia dan jenis kelamin, siswa dengan prestasi rendah ternyata melakukan kecurangan lebih banyak di banding dengan siswa dengan prestasi yang baik. siswa dengan latar belakang keluarga berpendidikan tinggi memiliki kesiapan lebih baik dalam mengerjakan tugas dibading siswa dari latarbelakang keluarga dengan tingkat pendidikan rendah. Fakta unik lain yang terungkap adalah bahwa siswa yang terlibat dalam kegiatan ekstrakurikuler memiliki komitmen lebih rendah berkaitan dengan pendidikan.

b. Faktor kepribadian siswa. Beberapa faktor yang berkaitan dengan kepribadian siswa yang dapat memunculkan perilaku curang adala sebagai berikut.

1) Moralitas yang diukur dari tingkat kejujuran dan religiusitas. Di mana siswa yang berada pada level kejujuran rendah memiliki kecenderungan untukmelakukan kecurangan. Sama hal nya dengan level kejujuran, siswa dengan religiusitas yang rendah juga cenderung lebih banyak melakukan kecurangan.

2) Selain moralitas, variabel yang berkaitan dengan pencapaian 
akademis adalah motivasi, pola kepribadian dan pengharapan terhadap kesuksesan. Motivasi berprestasi dalam memenangkankompetesi seringkali berdampak pada peningkatan kecenderungan berbuat curang. Berbeda dengan motivasi, pola kepribadian dan pengharapan terhadap kesuksesan justru memiliki hubungan negatif dengan perilaku curang.

3) Impulsivitas, afektivitas dan variabel kepribadia yang diukur dari tingkat kecemasan. Berdasarkan hasil pengukurang diketahuibahwa siswa yang memiliki level kecemasan yang tinggi menunjukkan kecenderungan untuk berbuat curang.

c. Faktor kontekstual yaitu, perkumpulan siswa, perilaku teman sebaya, serta penolakan teman sebaya terhadap perilaku curang. Siswa yang mengikuti perkumpulan atau perhimpunan ternyata memiliki kecenderungan lebih sering berperilaku curang. Hal itu disebabkan karena dalam sebuah perkumpulan, penyediaan catatan ujian, tugas laboratorium serta tugas akademik lebih mudah diperoleh. Berdasarkan teori pembelajaran sosial (social learning theory) yang dikemukakan oleh Bandura dan teori hubungan perbedaan (differential associaton) yang dikemukakan oleh Edwin Sutherlanddapat dijadikan pendukung hipotesis bahwa perilaku teman sebaya yang menyimpang akan memberikan pengaruh terhadap perilaku individu yang menirunya.Namun sebaliknya, apabila terdapat penolakan perilaku menyimpang oleh teman sebaya, maka hal tersebut akan membawa dampak positif bagi penirunya.

d. Faktor situasional di mana siswa yang memiliki anggapan bahwa dirinya berkompetisi dengan siswa lain serta terlalu banyak menghabiskan memiliki kecenderungan lebih besar untuk berbuat curang bila dibandingkan siswa dengan situasi sebaliknya. Disisi lain, lingkungan ujian yang memberikan pemikiran kepada siswa mengenai rendahnya resiko diketahui berbuat curang akan meningkatkan kecenderungan berbuat curang.

Selain faktor di atas terdapat juga beberapa faktor yang menjadi penyebab kecurangan akademik. Seperti yang dikemukakan oleh Alhadza (2001) terdapat empat faktor yang menjadi penyebab kecurangan akademik yaitu, (1) faktor individual, (2) factor lingkungan atau pengaruh kelompok, serta (3) faktor sistem evaluasi dan faktor guru. Seperti yang telah dikemukakan sebelumnya bahwa kecenderungan berbuat curang oleh individu dipengaruhi oleh motivasi baik intrinsik maupun ekstrinsik.

Pengaruh lingkungan atau kelompok mengacu pada teori pembelajaran sosial dan teori hubungan perbedaan. Perbedaan menarik dari pendapat ini adalah faktor sistem evaluasi dan faktor guru. Sistem evaluasi yang buruk seperti, (1) tidak adanya relevansi antara materi dan soal ujian, (2) tidak adanya pedoman penilaian yang jelas, serta (3) rendahnya akuntabilitas perkembangan hasil belajar akan meningkatkan kecenderungan siswa untuk berbuat curang. Faktor ini berhubungan dengan kompetensi profesional guru. 
Kecenderungan berbuat curang akan lebih kuat apabila siswa memiliki anggapan bahwa hasil kerja mereka tidak dikoreksi. Bentuk kecurangan yang umum adalah plagiarisme atau perilaku meniru secara utuh hasil pekerjaan siswa lain. Keadaan ini seringkali dipengaruhi oleh kurangnya waktu guru disebabkan terlalu banyaknya jam mengajar sehingga aktivitas koreksi dan pelaporan hasil belajar siswa seringkali terbengkalai.

\section{Rubrik Penskoran}

Rubrik penskoran merupakan bagian dari rencana pembelajaran yang termuat dalam aktivitas evaluasi maupun penugasan. Menurut Smith (2003). Design inntructional harus memuat setidaknya tiga aktivitas utama yaitu (1) analisis, (2) strategi, (3) evaluasi. Dalam kegiatan evaluasi tersebut harus ditulis pula bentuk tes formatif sesuai dengan analisis isi pelajaran, kompetensi siswa dan tugas yang akan diberikan kepada siswa. Model lain dikemukakan oleh Dick dan Carey (2005).Model pembelajaran tersebut dikembangkan melalui pendekatan sistem (System Approach). Diuraikan lebih lanjut bahwa komponen-komponen dasar dari desain sistem pembelajaran mencaku lima komponen inti yaitu, (1) analisis, (2) implementasi yang terdiri dari desain dan pengembangan, serta (3) evaluasi.Dick dan Carey mengatakan bahwa dalam kegiatan evaluasi tersebut harus dituliskan intrumen tes formatif maupun tes sumatif.

Rubrik adalah dokumen yang mengungkapkan harapan untuk tugas, atau seperangkat tugas, melalui daftar kriteria penilaian dengan menjelaskan tingkat kualitas kaitannya dengan masing-masing kriteria (Reddy\&Andrade, 2010). Menurut Slavin (2005) rubrik penskoran dibutuhkan untuk melakukan assessing dalam penilaian auntentik atau disebut dengan performance asessment. Performance assessment merupakan bentuk penskoran berdasarkan rubrik yang secara spesifik mengembangkan dalam bentuk unjuk kerja yang yang diharapkan mampu dikuasai sebagai penunjang dalam menguasai aktivitas lainnya.Menurut Slavin (2005), format rubrik penskoran terdiri dari 3 hal yaitu, (1) unjuk kerja (performance), (2) kriteria unjuk kerja (performance criteria), serta (3) rubrik penskoran (scoring rubric).

Meskipun rubrik digunakan pada berbagai unjuk kerja dan menunjukkan pengaruh yang berbeda, namun yang pasti rubrik dapat memberikan pengaruh positif terhadap hasil belajar siswa melalui faktor sebagai berikut.

a. Meningkatkan transparansi. Melalui rubrik, siswa akan lebih mengerti berkenaan dengan maksud atau apa yang diharapkan guru atas tugas atau materi tertentu (Andrade \& Du, 2005; Reynolds-keefer, 2010)

b. Mengurangi kecemasan. Rubrik akan memberikan kejelasan mengenai sebuah topik tertentu dalam pembelajaran. Kejelasan tersebut memberikan peningkatan terhadap kepercayaan diri siswa dan membuat siswa lebih mudah mengerjakan soal sehingga mereka memilikikeyakinan lebih besar mengenai ketepatan dalam menjawab soal yang menyebabkan kecemasan menjadi menurun (Kuhl, 2000;)

c. Membantu proses umpan balik. Proses umpan balik tersebut diperoleh melalui proses review yang dilakukan oleh siswa atas skor yang telah diperoleh (Andrade\&Du, 2005)

d. Meningkatkan kepercayaan diri siswa. Peningkatan kepercayaan diri tersebut 
terutama tampak pada penggunaan rubrik dalam soal essay sehingga penjelasakan yang dikemukakan dalam kunci jawaban lebih realistis Dinther, dkk (2010).

e. Mendungan pengaturan diri sendiri siswa. Penelitian yang dilakukan Panadero \& Jonsson (2013) menunjukkan bahwa rubrik mampu memberikan fasilitas terhadap perencanaan dan penilaian diri sendiri seperti kemajuan evaluasi diri secara kontinu dalam bentuk penggunaan rubrik sebagai acuan dalam upaya merencanakan pendekatan dalam mengerjakan ujian.

\section{Masalah Ekonomi}

Para ahli ekonomi mengatakan bahwa masalah ekonomi dapat dikaitkan dengan kebutuhan membuat pilihan. Pernyataan tersebut mengandung arti bahwa pilihan yang dibuat adalah mengenai cara terbaik untuk melakukan kegiatan ekonomi. Kegiatan ekonomi sendiri dapat diartikan sebagai kegiatan masyarakat atau perusahaan untuk memproduksi maupun mengkonsumsi barang dan jasa tersebut. Menurut Sukirno (2010) usaha tersebut dilatarbelakangi oleh masalah pokok ekonomi yaitu kelangkaan yang disebabkan karena adaya ketidak seimbangan antara kebutuhan manusia dengan sumberdaya pendukungnya. Dengan kata lain bahwa kebutuhan manusia bersifat tidak terbatas sedangkan alat pemuas kebutuhan bersifat terbatas.

Menganalisis masalah ekonomi merupakan salah satu kompetensi dasar mata pelajaran ekonomi kelas X SMA. Kompetensi tersebut diatur dalam Lampiran Peraturan Menteri Pendidikan dan Kebudayaan (Permendikbud) Nomor 64 Tahun 2013 Tentang Standar Isi khususnya pada muatan ekonomi untuk peminatan ilmu sosial tingkat kompetensi 5 kelas X. Seterusnya dalam silabus SMA kompetensi tersebut dirinci dengan bentuk capaian pembelajaran yaitu menganalisis masalah ekonomi dan cara mengatasinya.

Rincian materi yang umum disajikan guna menguraikan lebih lanjut mengenai permasalahan ekonomi adalah sebagai berikut.

a. Masalah Ekonomi dan cara mengatasinya

1) Inti masalah ekonomi/Kelangkaan

2) Biaya peluang

3) Skala prioritas

4) Permasalahan pokok ekonomi (apa, bagaimana, untuk siapa barang diproduksi)

Mengacu pada kajian literatur, seperti yang sudah dijelaskan sebelumnya bahwa inti dari masalah ekonomi adalah kelangkaan. Dengan adanya kelangkaan tersebut, individu, masyarakat maupun perusahaan dihadapkan pada keputusan membuat pilihan dalam memproduksi maupun melakukan konsumsi. Sukirno (2010) mengatakan bahwa tujuan dari keputusan tersebut adalah untuk memaksimalkan kesejahteraan yang diukur dari efisiensi penggunaan sumberdaya. Oleh sebab itu, Mankiew (2015) mengatakan bahwa ekonom (pakar ekonomi) mencoba untuk menempatkan diri merekasebagai seorang ilmuwan dengan membuat berbagai model yang digunakan untuk menjelaskan berbagai permasalahan ekonomi sehingga efisiensi penggunaan sumberdaya lebih mudah tercapai.

Keputusan membuat pilihan dan biaya peluang (oportunity cost) 
memiliki keterkaitan yang erat.Adanya kelangkaan mendorongin dividu, masyarakat maupun perusahaan untuk membuat pilihan yang rasional atau menenetukan skala prioritas. Dengan membuat pilihan, individu, masyarakat maupun perusahaanakan kehilangan kesempatan untuk memperoleh barang atau faktor produksi lain. Oleh sebab itu, oportunity cost dapat di definisikan sebagai pengorbanan, bisa berupa sumberdaya maupun biaya yang hilang karena hilangnya kesempatan akibat dari pemenuhan kebutuhan lain.Konsep Oportunity cost dapat digambarkan dengan menggunakan production possibility frontier (PPF). PPF merupakan jumlah produksi yang dapat dicapai oleh suatu perekonomian, dengan menggunakan sumberdaya yang terbaik melalui ketersedian teknologi dan faktor produksi. PPF pada umumnya disajikan dalam bentuk grafik yang dapat dicontohkan sebagai berikut.

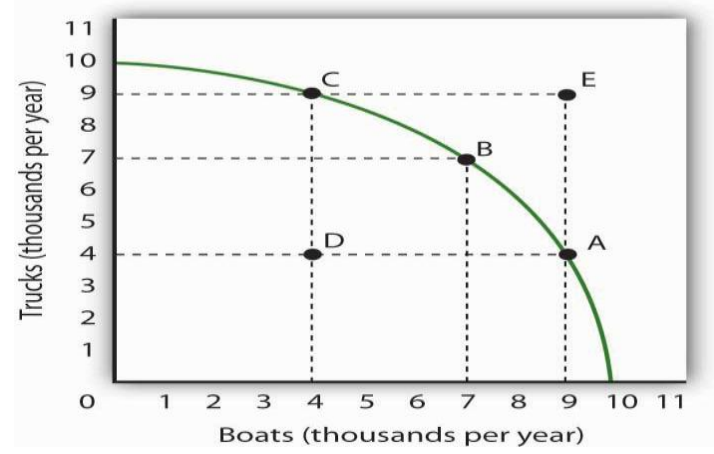

Kurva 1.1 Kurva production possibility frontier (PPF) Sumber :http://2012 books.lardbucket.org/books/economics -principles-v1.0/s20-01-the-gainsfromtrade.html

Menurut Sukirno (2010) PPF menggunakan beberapa asumsi yaitu, (1) faktor produksi sepenuhnya digunakan, (2) faktor produksi tetap, (3) teknologi tidak mengalami perubahan, (4) hanya terdapat dua macam barang yang diprodukasi, (5) biaya kesempatan semakin meningkat. Ilustrasi di atas dapat menjelaskan bahwa pilihan paling ideal yang dapat dilakukan perusahaan dalam memproduksi truk dan boat berada pada titik E di mana jumlah produksi truk dan kapal beradapa pada jumlah maksimal yaitu 9. Berdasarkan kurva tersebut dapat dijelaskan apabila perusahaan memilih memproduksi truk sebesar 9 unit, maka perusahaan harus mengorbankan 5 unit boat (pada titik C).

Terdapat beberapa masalah yang terjadi ketika individu, masyarakat maupun perusahaan melakukan kegiatan ekonomi. Permasalahan tersebut setidaknya dapat di rumuskan dalam tiga bentuk pertanyaan yaitu, (1) apa yang akan diproduksi?, (2) bagaimana cara memproduksi?, serta (3) untuk siapa barang diproduksi?. Sukirno (2010) mencoba merumuskan jawaban pertanyaan pertama menggunakan konsep pilihan dalam memproduksi. Dalam perekonomian, perusahaan dikembangkan untuk memproduksi barang dan jasa yang dibutuhkan oleh individu, masyarakat maupun negara. Hasil akhir dari kegiatan tersebut adalah keuntungan maksimum. Oleh sebab itu, perusahaan akan berusaha untuk menentukan jenis, jumlah serta faktor produksi yang akan digunakan. Selain itu, perusahaan juga akan menentukan tingkat produksi yang mampu memberikan keuntungan paling tinggi melalui kombinasi faktor produksi dalam upaya meminimalkan biaya.

Tujuan dari adanya kombinasi adalah untuk memaksimalkan output. Jawaban untuk pertanyaan nomor dua yaitu "bagaimana memproduksi barang?, mengarah pada penggunaan teknologi dalam proses produksi. Teknologi 
digunakan untuk melakukan kombinasi faktor produksi yaitu, (1) tanah, (2) modal, serta (3) tenaga kerja. Ketiga faktor produksi tersebut merupakan input.

Salah satu variabel yang mempengaruhi daya beli masyarakat adalah jumlah pendapatan yang dimiliki. Apabila dikaitkan dengan pertanyaan yaitu "untuk siapa barang diproduksi?" maka akan mengarah pada konsumen yang membutuhkan dan memiliki jumlah

\section{METODE PENELITIAN}

Metode yang digunakan dalam menganalisis kecurangan akademik melalui analisis butir soal menggunakan format seperti yang dikemukakan Slavin (2005) yaitu, (1) unjuk kerja (performance), (2) kriteria unjuk kerja (performance criteria), serta (3) rubrik penskoran (scoring rubric). Secara lebih rinci, format rubrik penskoran tersebut tersebut dioperasionalkan sebagai berikut.

1. Unjuk Kerja (performance)

a. Menentukan kompetensi inti yang ingin di capai yaitu kejujuran;

b. Menentukan kompetensi dasar yaitu menganalisis masalah ekonomi

c. Menentukan kriteria pencapaian kompetensi dasar yaitu siswa dikatakan mampu menganalisis masalah ekonomi apabila memiliki pemahaman mengenai,

1) inti masalah ekonomi;

2) biaya peluang melalui kurve PPF;

3) kurva PPF;

4) pertanyaan apa, bagaimana, untuk siapa barang diproduksi berdasarkan studi kasus;

d. Menulis soal tes formatif; pendapatan yang cukup untuk melakukan konsumsi atas barang tersebut. Oleh sebab itu, dibutuhkan penelitian yang mendalam agar dapat diketahui secara lebih pasti mengenai pola konsumsi mengenai produk alternatif yang dikonsumsi dan pendapatan masyarakat dalam upaya memasarkan sebuah produk.

\section{Tabel 1.1 Data PPF}

Soal tes formatif dapat ditulis sebagai berikut.

1) Jelaskan inti masalah ekonomi.

2) Perhatikan tabel berikut

Tabel 1.1 Data PPF

\begin{tabular}{|l|c|c|}
\hline \multirow{2}{*}{ No } & \multicolumn{2}{|c|}{ Barang yang diproduksi } \\
\cline { 2 - 3 } & Kue bandung & Martabak \\
\hline 1 & 9 & 4 \\
\hline 2 & 7 & 7 \\
\hline 3 & 4 & 9 \\
\hline
\end{tabular}

3) Gambarlah kurva PPF.

4) Deskripsikan kurva PPF tersebut.

5) Jelaskan variabel yang mempengaruhi daya beli masyarakat.

2. Kriteria Unjuk Kerja dan Rubrik Penskoran.

a. Merancang kunci jawaban dan rubrik penskoran 
Tabel 1.2 Pedoman Penskoran

\begin{tabular}{|c|c|c|c|}
\hline No & Jawaban & Pedoman Penskoran & $\begin{array}{c}\text { Skor } \\
\text { Maksi } \\
\text { mal }\end{array}$ \\
\hline 1 & $\begin{array}{l}\text { Inti masalah ekonomi adalah } \\
\text { kelangkaan yang disebabkan karena } \\
\text { adaya ketidakseimbanganantara } \\
\text { kebutuhan manusia dengan } \\
\text { sumberdaya pendukungnya. }\end{array}$ & $\begin{array}{l}\text { Di dalam kunci jawaban terdapat } 4 \text { kata } \\
\text { kunci yang dicetak tebal dan diberi garis } \\
\text { bawah. Siswa akan mendapat skor } 1 \\
\text { apabila menyebutkan } 1 \text { kata kunci. }\end{array}$ & 4 \\
\hline 2 & Kue Bandung & $\begin{array}{l}\text { Keterangan: } \\
\text { Kurva digambar dengan benar apabila } \\
\text { memuat, (1) garis vertikal (Y) dan } \\
\text { horisontal (X), (2) skala (nilai X dan Y), } \\
\text { (3) garis penghubung, (4) keterangan } \\
\text { titik bertemunya X dan Y serta titik } \\
\text { 1) Kurva digambarkan sangat benar } \\
\text { apabila memuat empat keterangan } \\
\text { yaitu nomor } 1,2,3 \text { dan } 4 \text {. } \\
\text { 2) Kurva digambarkan benar apabila } \\
\text { memuat tiga keterangan } \\
\text { 3) Kurva digambarkan cukup benar } \\
\text { apabila memuat dua keterangan } \\
\text { 4) Kurva digambarkan tidak benar } \\
\text { apabila memuat satu keterangan }\end{array}$ & $\begin{array}{l}3 \\
2\end{array}$ \\
\hline 3 & $\begin{array}{l}\text { Pilihan paling ideal yang dapat } \\
\text { dilakukan perusahaan dalam } \\
\text { memproduksi kue bandung dan } \\
\text { martabak berada pada titik E di } \\
\text { mana jumlah produksi truk dan } \\
\text { kapal beradapa pada jumlah } \\
\text { maksimal yaitu } 7 . \text { Apabila } \\
\text { perusahaan memilih memproduksi } \\
\text { kue bandung sebesar } 9 \text { unit, maka } \\
\text { perusahaan harus mengorbankan } 5 \\
\text { unit martabak (pada titik C) }\end{array}$ & $\begin{array}{l}\text { 1. Siswa mampu menjelaskan titik } \\
\text { yang menunjukkan pilihan paling } \\
\text { ideal dalam memproduksi dua jenis } \\
\text { barang dan siswa mampu } \\
\text { menjelaskan berapa jumlah } \\
\text { barang yang harus dikorbankan } \\
\text { untuk memperoleh barang dalam } \\
\text { jumlah tertentu. } \\
\text { 2. Siswa belum mampu menjelaskan } \\
\text { titik yang menunjukkan pilihan } \\
\text { paling ideal dalam memproduksi dua } \\
\text { jenis barang dan siswa mampu } \\
\text { menjelaskan berapa jumlah } \\
\text { barang yang harus dikorbankan } \\
\text { untuk memperoleh barang dalam } \\
\text { jumlah tertentu. }\end{array}$ & 4 \\
\hline
\end{tabular}




\begin{tabular}{|c|c|c|c|}
\hline & & $\begin{array}{l}\text { 3. Siswa mampu menjelaskan titik } \\
\text { yang menunjukkan pilihan paling } \\
\text { ideal dalam memproduksi dua jenis } \\
\text { barang dan siswa belum mampu } \\
\text { menjelaskan berapa jumlah } \\
\text { barang yang harus dikorbankan } \\
\text { untuk memperoleh barang dalam } \\
\text { jumlah tertentu. } \\
\text { 4. Siswa belum mampu menjelaskan } \\
\text { titik yang menunjukkan pilihan } \\
\text { paling ideal dalam memproduksi dua } \\
\text { jenis barang dan siswa belum } \\
\text { mampu menjelaskan berapa } \\
\text { jumlah barang yang harus } \\
\text { dikorbankan untuk memperoleh } \\
\text { barang dalam jumlah tertentu. }\end{array}$ & 1 \\
\hline 4 & 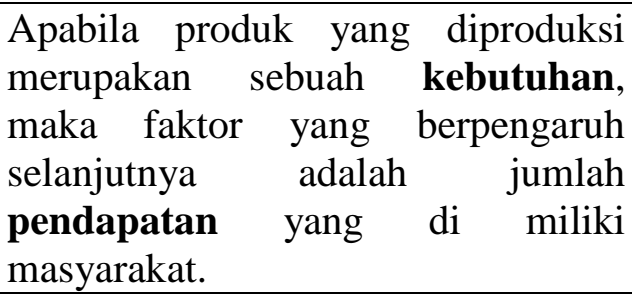 & $\begin{array}{l}\text { Setiap kata kunci yang di sebutkan } \\
\text { memiliki skor } 1\end{array}$ & 2 \\
\hline
\end{tabular}

b. Merancang format daftar skoring, seperti contoh dalam tabel berikut.

Tabel 1.3 Format Penskoran

\begin{tabular}{|c|c|c|c|c|c|c|c|c|c|c|c|c|c|}
\hline \multirow{2}{*}{$\begin{array}{l}\mathrm{N} \\
\mathrm{O}\end{array}$} & \multirow{2}{*}{$\begin{array}{c}\text { NAM } \\
\text { A } \\
\text { SISW } \\
\text { A }\end{array}$} & \multicolumn{10}{|c|}{ SKOR SOAL NOMOR } & \multirow{2}{*}{$\begin{array}{c}\mathrm{JM} \\
\mathrm{L}\end{array}$} & \multirow{2}{*}{$\begin{array}{c}\text { SKOR } \\
\text { TOTA } \\
\quad \text { L }\end{array}$} \\
\hline & & 1 & 2 & 3 & 4 & 5 & 6 & 7 & 8 & 9 & 10 & & \\
\hline & & & & & & & & & & & & & \\
\hline
\end{tabular}

3. Prosedur analisis

a. Pengisian kolom skoring berdasarkan hasil koreksi siwa A pada soal nomor 1, siwa A pada soal nomor 2, siwa A pada soal nomor 3, siwa A pada soal nomor
4, siwa B pada soal nomor, siwa B pada soal nomor 2, siwa B pada soal nomor 3, siwa B pada soal nomor 4 dan seterusnya sehingga dihasilkan data sebagai berikut.

Tabel 1.4 Hasil Penskoran

\begin{tabular}{|c|c|c|c|c|c|c|c|}
\hline \multirow[t]{2}{*}{ NO } & \multirow{2}{*}{$\begin{array}{l}\text { NAMA } \\
\text { SISWA }\end{array}$} & \multicolumn{4}{|c|}{$\begin{array}{l}\text { SKOR SOAL } \\
\text { NOMOR }\end{array}$} & \multirow[t]{2}{*}{ JML } & \multirow{2}{*}{$\begin{array}{l}\text { SKOR* } \\
\text { TOTAL }\end{array}$} \\
\hline & & 1 & 2 & 3 & 4 & & \\
\hline 1 & A & 2 & 4 & 3 & 4 & 13 & 81.25 \\
\hline 2 & B & 2 & 3 & 3 & 4 & 12 & 75 \\
\hline 3 & $\bar{C}$ & 2 & 4 & 2 & 1 & 9 & 56.25 \\
\hline 4 & $\mathrm{D}$ & 2 & 4 & 3 & 4 & 13 & 81.25 \\
\hline
\end{tabular}




\begin{tabular}{|l|l|l|l|l|l|l|r|}
5 & $\mathrm{E}$ & 2 & 4 & 3 & 2 & 11 & 68.75 \\
\hline 6 & $\mathrm{~F}$ & 2 & 4 & 3 & 1 & 10 & 62.5 \\
\hline
\end{tabular}

Sumber : data diolah

*Skor maksimal idela $(\mathrm{SMI})=2+4+3+6=15$

$$
\text { Skor total }=\left(\frac{\text { Jumlah skor yang diperoleh }}{\text { SMI }}\right) \times 100
$$

b. Mengidentifikasi kesamaan skor total.

Skor total sama teridentifikasi pada siswa dengan nama A dan B. Berdasarkan tabel tersebut pada cell yang di beri warna merah dan hijau, apabila diketahui tempat duduk berdekatan dan 50\% jawaban ditulis dengan data yang sama, maka dapat disimpulkan bahwa ada kecenderungan terjadi kecurangan akademik dalam betuk kerja sama

c. Mengidentifikasi kedekatan tempat duduk;

Agar tidak terdapat perubahan dalam posisi tempat duduk, sebaiknya hasil pekerjaan tes formatif langsung dikoreksi menggunakan metode koreksi silang oleh siswa. Syarat metode ini hanya siswa tidak boleh melakukan koreksi terhadap hasil pekerjaannya sendiri. Sebagai pemisalan, siswa A dan D ternyata duduk bersebelahan atau berdekatan.

d. Mengidentifikasi kesamaan jawaban yang di tulis;

Sebagai pemisalan, jawaban yang ditulis menunjukkan kesamaan autentik yang diperkirakan lebih dari $50 \%$.

e. Menetapkan kesimpulan;

1) Siswa dikatakan tidak jujur apabila lebih dari 50\% jawaban di tulis menggunakan kalimat yang sama.

2) Siswa dikatakan jujur apabila lebih dari $50 \%$ jawaban di tulis menggunakan kalimat yang berbeda

Perlu di ketahui bahwa kesimpulan tersebut bukan merupakan sebuah kemutlakan. Hasil kesimpulan dapat dijadikan sebagai bukti yang mendukung pelabelan atas ketidakjujuran yang telah dilakukan. Apabila dalam investigasi ternyata siswa memang melakukan kecurangan akademik, langkah selanjutnya adalah melakukan pembinaan dan penanaman karakter melalui bimbingan individu.

\section{KESIMPULAN}

Berdasarkan uraian dalam artikel ini dapat disimpulkan bahwa analisis kecurangan akademik melalui metode rubrik penskoran dapat dilakukan melalui tiga langkah pokok yaitu,(1) unjuk kerja (performance), (2) kriteria unjuk kerja (performance criteria), serta (3) rubrik penskoran (scoring rubric). Hasil analisis tersebut selanjutnya digunakan sebagai data dalam menentukan keputusan mengenai kecurangan akademik yang dilakukan siswa. Keputusan tersebut dapat dilanjutkan dengan perencanaan program bimbingan individu maupun kelompok sebagai tindakan prefentif untuk mencegah terjadinya kecurangan selanjutnya.

Penelitian lebih lanjut dapat dilakukan untuk memperoleh data 
mengenai pengaruh metode rubrik penskoran terhadap motivasi melakukan kecurangan akademik. Penelitian tersebut dilakukan untuk mengungkap apakah metode rubrik penskoran dapat memberikan afek terhadap kecurangan akademik.

\section{DAFTAR PUSTAKA}

Alhadza, A. 2001. Masalah Mencontek (Cheating) di Dunia Pendidikan. (Online). (http://www.depdiknas.go.id, diakses pada 20 Oktober 2016).

Andrade, H., \& Du, Y. 2005. Student perspectives on rubric-referenced assessment. Practical Assessment, Research\&Evaluation,10 (3), 1-11. Retrieved from http:// pareonline. net/getvn.asp?v $=10 \& n=3$

Davis, S.F., \& Ludvigson, H. W. 1995. Additional data on academic dishonesty and proposal for remediation. Teaching of Psychology, 19, 16-20.

Davy, Jeanette A., Kincaid, Joel F., Smith, Kenneth J., Trawick, Michelle A.2007. An Examination of the Role of Attitudinal Characteristics and Motivation on the Cheating Behavior of Bussiness Students. Ethcs \& Behavior. Routledge. 17(3). 281-302.

Dick, W., Carey, L., \& Carey, L. (2005).The systematic design of Instructional design: International perspectives (Vol. 1). Mahwah, instruction (6th ed.). New York, NY: HarperCollins.

Endra Murti Sagoro. 2013. Pensinergian Mahasiswa, Dosen, dan Lembaga dalam Pencegahan Kecurangan
Akademik Mahasiswa Akuntansi. Jurnal Pendidikan Akuntansi Indonesia, Vol. XI. XI, No. 2 : 54-67

Hendriks, B. 2004. Academic Dishonesty : A Study In The Magnitude of And Justifications For Academic Dishonesty Among College Undergraduate And Graduate Students. New Jersey : Roman University

Kuhl, J. 2000.A fumctional-design approach to motivation and selfregulation. In M.Boekaerts, P.R. Pitric, \& M.Zeidner (Eds.), Handbook of self-regulation (pp, 111-169). San Diego, CA: Academic Press.

Lambert, E.G., Hogan, N.L., \& Barton, S.M. 2003. Collegiate academic dishonesty revisited: what habe they done, how often habe they done it, who does it, and why did they do it. Electronic Journal of Sosiology. (http:/ /www.sociology. org/content /vol7.4/ lambert_etal.html), diakses pada 20 Oktober 2016.

Mankiew,N. Gregory. 2015. Principles Of Micro Economics. USA: Cengage Learning.

http://2012books.lardbucket.org/boo ks/economics-principles-v1.0/s2001-the-gains-from-trade.html.

Nonis, S. \& C. Swift. 2001.An Examination of Relationship Between Academic Dishonesty and Workplace Dishonesty: A Multicampus Investigation. Jurnal of Education for Business.

Nonis, S.A., \& Swift, C.O. 1998. Cheating behavior in the marketing classroom: An analysis of the effects of demographics, attitudes, and inclass deterrent strategies. Jouran of marketing educatioan, 20, 188-199. 
Panadero, E. 2011. Instructional help for self-assessment and self-regulation: Evaluation of the efficacy of selfassessment scripts vs. rubrics. Doctoral dissertation. Universidad Autónoma de Madrid, Madrid, Spain.

Panadero, Ernesto \& Jonsson, Anders. 2013. The Use of scoring rubrica for formative assessment purposes revised: A review. Elsevier. Educational Research Review 9 (2013) 129-144.

Pudjiastuti, Endang. 2012. Hubungan Self Efficacy dengan Perilaku Mencontek Mahasiswa Psikologi. Mimbar. Vol. XXVIII, No. 1 (Juni 2012: 103-112)

Reddy, Y.M.,\&Andrade, H. 2010. A Review of rubric use in higher education, Assessment\&Evaluation in Higher Education. Taylor \& Francis Online. Journal Assessment \& Evaluation in Higher Education. 35(4), 435-448.
Reynolds-Keefer, L, 2010. Rubricreferenced assessment in teacher preparation: An opportunity to learn by using. Practical Assessment Research \& Evaluation, 15(8), Retrieved from Retrieved from http://pareonline.net/getvn.asp? $\mathrm{v}=15$ $\& n=8$.

Sadono, Sukirno. 2010. Mikro Ekonomi. Teori Pengantar. Edisi Ketiga. Jakarta: PT. Raja Grafindo Persada.

Slavin. R. E 2005. Educational Psychology_ Theory and Practice (8th Edition)-Allyn \& Bacon.

Smith, Patricia L; Ragan, Tillman J. 2003. Instructional Design, Second Edition. Newyork: Wiley.

Van Dinther, M., Dochy, F., \& Segers, M. 2010. Factors affecting students selfefficacy in higher education. Educational Researchh Review, 6(2), 95-108. dx.doi .org/10. 1016/j. edurev. 2010.10.003. 